\title{
Sustainability Impacts in the IT Strategic Alignment
}

\author{
Antônio Palmeira de Araújo Neto, Ivanir Costa, Andréa Martins Cristóvão, \\ and Nilo Costa Serpa
}

\author{
Paulista University-UNIP, Graduate Program in Production Engineering, São Paulo, Brazil \\ antoniopalmeira@ig.com.br, icostallalive.com.br, \\ she_ra@uol.com.br, niloserpa@gmail.com
}

\begin{abstract}
Information Technology (IT) has been undergoing changes in their way of being governed. These changes has made proximity IT and business generating strategic alignment business, where business objectives are deployed in IT objectives. This strategic alignment may be affected and impacted for various external and internal factors to the business, including sustainability which is based on three pillars: economic, social and environmental. The aim of this paper is to evaluate the Influence of these three pillars in the IT strategic alignment processes, using the Delphi Method to obtain the IT experts consensus about influence on these processes. The main result shows there is preponderance that of the Influence of the economic pillar in most cases, but that the social and environmental pillars are already considered relevant processes in risk management and strategic planning.
\end{abstract}

Keywords: COBIT, IT Governance, Sustainability, Green IT, Sustainable IT.

\section{Introduction}

The evolution that the Information Technology (IT) area has experienced in recent years has generated greater integration with corporate business areas. This integration has meant that IT area support increasingly competitive advantages and add value for business strategy. As a result, boards of directors have been concerned with the IT responsibilities, controls and targets, in other words, emerged the IT governance need $[1 ; 2 ; 3]$.

IT Governance is responsibility of board of directors in the definition of leadership aspects, organizational structures and processes to ensure that IT supports and extends the organization's goals. One of the main implementation governance consequences in Enterprises is the emergence of the IT strategic alignment, which is also considered one of the focus areas, aiming to sustain the relationship between business plans and IT, align IT operations with the business, defining the value proposition $[1 ; 4 ; 5 ; 6 ; 7]$.

The COBIT Model, one of the most widely used in IT Governance, is based on the use of processes and controls, divided into four domains, mapped in five IT governance focus areas. The domains are: Plan and Organise (PO); Acquire and Implement (AI); Deliver and Support (DS), Monitoring and Evaluation (ME). The 
focus areas are: Strategic Alignment; Value Delivery; Resource Management; Risk Management; Performance Monitoring [5].

Strategic Alignment is impacted by factors resulting from internal and external environments to the business. Among the external factors, sustainability is one of that impact not only the IT strategic alignment but the entire organizational environment. Sustainability is designed as the capacity to meet the present generation needs without compromising the future generations ability to meet their own needs. Sustainability is achieved through the integration of three dimensions also known by pillars, forming a theory of the Triple Bottom Line (TBL). The three pillars are: economic, social and environmental $[8 ; 9 ; 10 ; 11 ; 12]$.

Energy savings in data centers, virtualization, consumables planning disposal, use of suppliers with the sustainable practices and Green IT practices are some of the consequences of the sustainability impacts in IT strategic alignment $[13 ; 14 ; 15 ; 16]$.

Believing in the existence of these impacts and influences, the this article purpose is to evaluate qualitatively the pillars influence of the TBL in the IT strategic alignment processes. Specifically, the evaluated processes integrate domain PO COBIT model.

\section{Methodology}

The paper object consists of two sets of elements: PO domain Processes, which map the Strategic Alignment; pillars of sustainability. The PO domain choice gave up just by being in it that starts the alignment between IT and Business. The processes studied were: Define a strategic IT plan; Define the information architecture; Communicate management aims and direction; Manage IT human resources; Manage quality; Assess and manage IT risks; Manage projects [4].

Once entries are important elements in a process, an sustainability influence analysis was performed on each input the PO domain processes. Table 1 shows the number of inputs on each PO domain process.

Table 1. Numbers of processes inputs

\begin{tabular}{lll}
\hline $\begin{array}{l}\text { Process } \\
\text { Code }\end{array}$ & Process & Total input \\
\hline PO1 & Define a strategic IT plan & 10 \\
PO2 & Define the information architecture & 5 \\
PO6 & Communicate management aims and direction & 4 \\
PO7 & Manage IT human resources & 2 \\
PO8 & Manage quality & 3 \\
PO9 & Assess and manage IT risks & 8 \\
PO10 & Manage projects & 4 \\
\hline
\end{tabular}


The Delphi method was used for the analysis of each input and the response if they are not influenced by each pillar of sustainability, which was made from a consultation of experts. The choice of this method of research is justified because there is no large-scale distributed knowledge on the subject which favors consulting experts and not restricted to a survey on a larger scale $[17 ; 18 ; 19]$.

The Delphi method is conceptualized as a tool for identifying trends and processes to support decision making, possessing three basic characteristics: anonymity; controlled feedback and statistical group responses. The anonymity among respondents is the way to minimize the reciprocal influence between participants. The feedback controlled decreases noise that commonly arise in the participants interaction in a discussion. Statistical group responses reflects the opinion of the respondents appropriately aggregated around individual opinions predominant [17].

Iterations and feedback-controlled obtains a forecast that contains the view of the majority of research participants, where recommend participation from 10 to 18 experts in at least three iterative rounds $[17 ; 18]$.

In this study, thirteen IT experts were asked, where in the first round, respondents answered only multiple choices questions. From the second round questions were accompanied by a feedback from the previous round and the responses were accompanied by a review of each respondent. Some details about the IT expert can be seen in Table 2 .

Table 2. Detail about the IT expert

\begin{tabular}{lll}
\hline Level of education & Experience & Total expert \\
\hline Master degree & Academic and professional & 3 \\
Master degree & Academic & 3 \\
Doctoral degree & Academic and professional & 2 \\
Doctoral degree & Academic & 1 \\
Specialization & Academic and professional & 3 \\
Specialization & Professional & 1 \\
\hline
\end{tabular}

There were eight possible answers for each processes input: all pillars influence, no influence pillar, only economic pillar influences, only social pillar influences, only environmental pillar influences, and combinations two by two pillar influence. Consensus was considered when more than $50 \%$ of the respondents agree with one of these possibilities.

After the experts consensus about questions asked, we found the inputs percentage affected by sustainability pillars in each case, thereby establishing, through the scale shown in Table 3, the degree of influence. This scale Influence levels are based on the same Likert levels used in traditional surveys. 
Table 3. Influence scale of the processes

\begin{tabular}{lll}
\hline Level & Degree of Influence & Metrics \\
\hline 0 & Null & Process inputs are not influenced \\
1 & Low & Between $1 \%$ and $40 \%$ process inputs are influenced \\
2 & Average & Between $41 \%$ and $60 \%$ process inputs are influenced \\
3 & High & Between $61 \%$ and $99 \%$ process inputs are influenced \\
4 & Total & All inputs are influenced by the process \\
\hline
\end{tabular}

\section{Results and Discussion}

For the first round consensus was found in 28 of 36 entries, as seen in Table 4.

Table 4. First round result

\begin{tabular}{llll}
\hline Process Code & Input & Pillar & Consensus \\
\hline PO1 & Business strategy and priorities & All & $77 \%$ \\
PO1 & Enterprise Strategic direction for IT & All & $77 \%$ \\
PO1 & Programme portfolio & All & $62 \%$ \\
PO1 & Report on IT governance status & Economic & $69 \%$ \\
PO1 & New/updated service requirements & All & $54 \%$ \\
PO1 & Updated IT project portfolio & All & $54 \%$ \\
PO1 & Updated IT service portfolio & All & $54 \%$ \\
PO1 & Performance input to IT planning & Economic & $54 \%$ \\
PO1 & Cost-benefits reports & All & $54 \%$ \\
PO2 & Strategic and tactical IT plans & Economic & $54 \%$ \\
PO2 & Performance input to IT planning & Economic & $54 \%$ \\
PO2 & Performance and capacity information & Economic & $54 \%$ \\
PO2 & Post-implementation review & None & $54 \%$ \\
PO6 & Report on effectiveness of IT controls & Economic & $54 \%$ \\
PO6 & Strategic and tactical IT plans & Economic & $54 \%$ \\
PO6 & IT project and service portfolios & All & $54 \%$ \\
PO6 & IT-related risk management guidelines & Economic & $54 \%$ \\
PO8 & Strategic IT plans & Economic & $54 \%$ \\
\hline & & & \\
\hline
\end{tabular}


Table 4. (continued)

\begin{tabular}{llll}
\hline PO8 & Detailed project plans & All & $54 \%$ \\
PO8 & Remedial action plans & All & $54 \%$ \\
PO9 & Strategic and tactical IT plans & Economic & $54 \%$ \\
PO9 & IT service portfolio & All & $54 \%$ \\
PO9 & Enterprise appetite for IT risks & Economic & $54 \%$ \\
PO9 & Historical risk trends and events & All & $54 \%$ \\
PO9 & Security threats and vulnerabilities & All & $54 \%$ \\
PO9 & Contingency test results & All & $54 \%$ \\
PO10 & IT project portfolio & All & $54 \%$ \\
PO10 & Post-implementation review & None & $54 \%$ \\
\hline
\end{tabular}

After the second round consensus was reached in 6 inputs, as can be seen in Table 5. Two entries were pending with the consensus for the third round.

Table 5. Second round result

\begin{tabular}{lllc}
\hline Process Code & Input & Pillar & Consensus \\
\hline PO1 & Risk assessment & All & $100 \%$ \\
PO2 & Business requirements feasibility study & All & $83 \%$ \\
PO7 & Business requirements feasibility study & All & $83 \%$ \\
PO7 & Documented roles and responsibilities & None & $66 \%$ \\
PO9 & Project risk management plan & All & $66 \%$ \\
PO9 & Supplier risks & All & $83 \%$ \\
\hline
\end{tabular}

At the second round end there were still two inputs in which there was a consensus. Started the third round with questions and feddback controlled on 2 inputs with pending consensus. The consensus was reached at the third round end and Table 6 shows the result.

Table 6. Third round result

\begin{tabular}{lllc}
\hline Process Code & Input & Pillar & Consensus \\
\hline PO10 & IT skills matrix & Economic & $60 \%$ \\
PO10 & Development standards & None & $54 \%$ \\
\hline
\end{tabular}


From the information about the each pillar influence on each input and using the scale levels shown in Table 2, found the influence level of each pillar on each of the processes of strategic alignment in the PO domain. The results are shown in Table 7.

Table 7. Sustainability Influence in the Processes

\begin{tabular}{llll}
\hline & $\begin{array}{l}\text { Economi } \\
\mathbf{c} \text { Pillar }\end{array}$ & $\begin{array}{l}\text { Social } \\
\text { Pillar }\end{array}$ & $\begin{array}{l}\text { Environmenta } \\
\text { l Pillar }\end{array}$ \\
\hline Define a strategic IT plan & Total & High & High \\
Define the information architecture & High & Low & Low \\
Communicate management aims and direction & Total & Low & Average \\
Manage IT human resources & Average & Average & Average \\
Manage quality & High & Average & Average \\
Assess and manage IT risks & Total & High & High \\
Manage projects & Average & Low & Low \\
\hline
\end{tabular}

It is considered in the analysis processes for which the consensus percentage was greater in the first round have greater certainty in the art. The processes for which consensus took longer to be achieved and have greater doubts or lack of specialists.

Analyzing the data presented in Table 6, it was found that the pillar that most influences the processes contained within this study is the economic. It was also an influence almost similar between the social and environmental pillars. And more about the processes influenced by sustainability in general are the PO1 (Define a Strategic IT Plan) and PO9 (Assess and Manage Risk).

It is believed that the process PO1 Total influence of economic factors and the high social and environmental factors is due to the character's own IT strategic planning to deploy the corporate strategic planning, which considers sustainability in the following ways:

- Economic: making decisions based on profit increase, customers, brand value;

- Environmental: prioritizing strategies that less environmentally friendly;

- Social: the understanding of the role of the corporation in society.

The high influence in PO9 is understood due to sustainability always be included in the risk environment, as a matter considered by the management of corporations. The risk that IT poses to the company's image to society when there are established environmental strategies, or even the risk of IT investments must be considered. Disregarding the economic pillar, the other five cases examined (PO2, PO6, PO7, PO8 and PO10) receive an influence ranging from low-and middle pillar of sustainability. 


\section{Conclusions}

Given the goal of qualitative assessment of the degree of sustainability pillars influence, it appears that it was hit. The table with sustainability nfluence in IT processes found summarizes the experts perceptions about the economic, social and environmental pillars influence in the processes of the strategic alignment Plan and Organise (PO) of the COBIT model.

A possible continuation of this research can be given towards the use of the Delphi method to evaluate the influence of sustainability on other processes such as transaction, transition, architecture as well as in other areas of focus of governance.

This research was restricted to the COBIT model, but suggests the influence of sustainability assessment processes and / or practices of other models of management and IT governance, such as ITIL, CMMI, ISO2000, ISO38500, to discover correlations that help organizations to have their IT departments increasingly aligned to the concepts of sustainable development.

\section{References}

1. Tuttle, B., Vancervelde, S.D.: An empirical examination of CobiT as an internal control framework for information technology. International Journal of Accounting Information Systems 8, 240-263 (2007), http://www.sciencedirect.com/science/ article/pii/S14670895070004250 (accessed on: March 2013)

2. Luciano, E.M., Testa, M.G.: Controles de governança de tecnologia da informação para a terceirização de processos de negócio: uma proposta a partir do COBIT. JISTEM J. Inf. Syst. Technol. Manag. 8(1) (2011), http://www.scielo.br/scielo.php?script= sci_arttext\&pid=S1807-17752011000100012\&lng=en\&nrm=iso (accessed on: March 2013)

3. Lunardi, G.L., Becker, J.L., Macada, A.C.G.: Um estudo empírico do impacto da governança de TI no desempenho organizacional. Produção. São Paulo (2012), http://www.scielo.br/scielo.php?script=sci_arttext\&pid= S0103-65132012005000003\&lng =pt\&nrm=iso (accessed on: March 2013)

4. ISACA, CobiT $-4^{\text {th }}$ Edition (Version 4.1), 3rd edn. Information Systems Audit and Control Association, IT Governance Institute, Rolling Meadows, USA (2008)

5. ISO, Norma ISO/IEC 38500:2008 (2008)

6. Bernroider, E.W.N., Ivanov, M.: IT project management control and the Control Objectives for IT and related Technology (CobiT) framework. International Journal of Project Management 29, 325-336 (2011), http://www.sciencedirect.com/ science/article/pii/S0263786310000529 (accessed on: March 2013)

7. Weill, P., Ross, J.W.: IT governance-How top performers manage IT decision rights for superior results. Harvard Business School Press, Boston (2004)

8. Luftman, J.N., et al.: Transforming the Enterprise: the alignment of business and information technology strategies. IBM Systems Journal 32(1), 198-221 (1993)

9. Henderson, J.C., Venkatraman, N.: Strategic Alignment: Leveraging Information Technology For Transforming Organizations. IBM Systems Journal 32(1), 4-16 (1993) 
10. Elkington, J.: Triple bottom line revolution: reporting for the third millennium. Australian CPA 69, 75 (2013), http://www.cpaaustralia.com.au/apps/library/ itemdetails.aspx? itemno=89725 (accessed on: March 2013)

11. CMMAD. Nosso futuro comum. Fundação Getúlio Vargas, Rio de Janeiro (1991)

12. de Oliveira, L.R., et al.: Sustentabilidade: da evolução dos conceitos à implementação como estratégia nas organizações. Produção. São Paulo 22(1) (2012), http://www.scielo.br/scielo.php?script=sci_arttext\&pid= S0103-65132012000100006\&lng=en\&nrm=iso (accessed on: March 2013)

13. Bose, R., Luo, X.: Integrative framework for assessing firms' potential to undertake Green IT initiatives via virtualization - A theoretical perspective. Journal of Strategic Information Systems 20, 38-54 (2011), http://www.sciencedirect.com/ science/article/pii/S0963868711000047 (accessed on: March 2013)

14. Faucheux, S., Nicolai, I.: IT for green and green IT: A proposed typology of ecoinnovation. Ecological Economics 70, 2020-2027 (2011),

http: / / www. sciencedirect.com/science/article/pii/

S0921800911002084 (accessed on: March 2013)

15. Cristovão, A.M., Costa, I.: Virtualization: The Advantages of This New Paradigm in the It Landscape and the Positive Environmental Impact of This Technology. In: International Conference on Advances in Production Management Systems, Cernobbio, Italy (2010)

16. Joumaa, C., Kadry, S.: Green IT: Case studies. Energy Procedia 16, 1052-1058 (2012), http://www.sciencedirect.com/science/article/pii/ S1876610212001786 (accessed on: March 2013)

17. Dalkey, N.C.: The Delphi method: An Experimental Study of Group Opinion, The RAND Corporation, RM-5888-PR (1969)

18. Landeta, J.: Current validity of the Delphi method in social sciences. Technological Forecasting \& Social Change 73, 467-482 (2006)

19. Pill, J.: The Delphi Method: substance, context, a critique and an annotated bibliography. Socio-Econ. Plan. Sci. 5, 57-71 (1971) 